Terakreditasi Nasional Peringkat 3, DJPRP Kementerian Ristekdikti

No. 21/E/KPT/2018, Tanggal 9 Juli 2018

\title{
Studi Morfologi dan Morfometri Duodenum Anjing Kintamani
}

\section{(STUDY OF MORPHOLOGY AND MORFOMETRY KINTAMANI DOG DUODENUM)}

\section{Andika Diko Septiyatma $^{1 *}$, Ni Luh Eka Setiasih ${ }^{1}$, Luh Gde Sri Surya Heryani ${ }^{2}$}

\author{
${ }^{1}$ Laboratorium Histologi Veteriner, ${ }^{2}$ Laboratorium Anatomi Veteriner Fakultas Kedokteran \\ Hewan Universitas Udayana, Jln. PB. Sudirman, Denpasar, Bali. \\ *Email: andikavetmed@ gmail.com
}

\begin{abstract}
ABSTRAK
Anjing kintamani merupakan anjing asli Indonesia yang berasal dari Bali yang mempunyai penampilan menarik dan sangat indah. Tujuan dari penelitian ini adalah untuk mengetahui morfologi dan morfometri duodenum anjing kintamani. Penelitian ini menggunakan lima ekor anjing kintamani bali betina. Pengamatan terhadap morfologi histologi menggunakan mikroskop cahaya binokuler dengan pembesaran 5x, 10x, dan 20x. Hasil penelitian menunjukkan, panjang duodenum: 16,2 $\pm 1,3$ $\mathrm{cm}$, dan lebar duodenum $3,1 \pm 0,1 \mathrm{~cm}$. Struktur histologi duodenum tersusun atas empat lapisan meliputi: tunika mukosa, submukosa, muskularis, dan serosa. Ketebalan tunika mukosa: 1364,584 \pm $255,504 \mu \mathrm{m}$, tunika submukosa: $360,136 \pm 188,283 \mu \mathrm{m}$, tunika muskularis: $689,178 \pm 267,228 \mu \mathrm{m}$, tunika serosa: $25,888 \pm 11,93 \mu \mathrm{m}$.
\end{abstract}

Kata kunci: Anjing kintamani; morfologi; morfometri; duodenum.

\section{ABSTRACT}

The kintamani dog is a native dog from Bali that has an attractive and a gorgeous appearance. The aim of this research was to know the morphology and morphometry of kintamani dog's duodenum. This study used five female kintamani dogs. The observation of histologic morphology used a binocular light microscope with 5x, 10x, and 20x magnification. The results showed that length of duodenum is $16.2 \pm 1.3 \mathrm{~cm}$, and the width of duodenum are $3.1 \pm 0.1 \mathrm{~cm}$. The duodenal histology structure is composed of four layers: tunica mucosa, submucosa, muscularis, and serosa. Tunica mucosa thickness: 1,364.584 $\pm 255.504 \mu \mathrm{m}$, tunica submucosa: $360.136 \pm 188.283 \mu \mathrm{m}$, tunica muscularis: $689.178 \pm 267.228 \mu \mathrm{m}$, tunica serosa: $25.888 \pm 11.93 \mu \mathrm{m}$.

Keywords: Kintamani dog; morphology; morphometry; duodenum.

\section{PENDAHULUAN}

Anjing merupakan salah satu hewan yang dapat hidup berdampingan dengan manusia. Memelihara anjing merupakan suatu hal yang sering ditemukan dalam kehidupan bermasyarakat. Dahulu anjing hanya dijadikan peliharaan untuk menjaga rumah, namun sekarang sudah menjadi hewan kesayangan yang pemeliharaannya sangat diperhatikan (Wirawan, 2019). Indonesia memiliki anjing ras yang menjadi satu-satunya anjing ras asli Indonesia yaitu anjing kintamani. Anjing ini merupakan anjing lokal dataran tinggi, tinggal di sekitar Desa Sukawana, Kecamatan Kintamani, Kabupaten Bangli, Provinsi Bali, dan dalam sejarah, anjing ini disebut anjing gembrong (Puja, 2007). Anjing kintamani saat ini peminatnya semakin meningkat dikarenakan anjing kintamani merupakan satu-satunya anjing asli Indonesia yang mempunyai penampilan menarik (Gunawan et al., 2012).

Banyaknya peminat anjing kintamani ini tidak diimbangi dengan banyaknya penelitian tentang anjing kintamani. Dimana setiap ras anjing memiliki 
karakteristik yang berbeda-beda. Kajian tentang struktur anatomi dan morfometri duodenum pada anjing kintamani belum ada dilaporkan saat ini. Maka dari itu, perlu dilakukan penelitian tentang hal tersebut. Data atau informasi awal tentang struktur morfologi duodenum dapat dijadikan acuan untuk penelitian berikutnya seperti: patologi, imunologi, fisiologi, preklinik, dan klinik berikutnya.

\section{METODE PENELITIAN}

Penelitian ini menggunakan sampel berupa duodenum dari lima ekor anjing kintamani. Sampel diambil dari anjing kintamani betina pada saat program eliminasi (depopulasi) di Desa Sukawana.

Pengamatan struktur anatomi dilakukan dengan pengamatan langsung terhadap duodenum di dalam rongga abdomen. Adapun variabel yang diamati yakni berat, panjang, diameter lumen. Pengukuran dilakukan dengan menggunakan meteran kain dan jangka sorong digital berdasarkan variabel yang akan diamati. Pembuatan sedian histologi dilakukan mengacu pada metode yang digunakan oleh Luna (1968). Prosedur pewarnaan HE mengacu pada metode Kiernan (2010). Pengamatan struktur histologi dilakukan pada lima lapang pandang menggunakan mikroskop cahaya dengan pembesaran lensa objektif 50X, 100X, dan 200X (Suwiti et al., 2015). Variabel gambaran histologi yang diamati meliputi komponen dan lapisan duodenum. Pengukuran dilakukan di bawah mikroskop dengan menggunakan pembesaran lensa obyektif 50X, 100X dan 200X menggunakan carlzeiss teaching microscope.

\section{Cara Pengumpulan Data}

Data yang dikumpulkan yaitu dari hasil pengamatan anatomi dan histologi. Data anatomi diperoleh dari hasil pengamatan morfologi dan pengukuran panjang dan lebar dengan cara membuka duodenum kemudian diukur menggunakan meteran kain. Data histologi diperoleh dari hasil pengamatan morfologi dan pengukuran ketebalan lapisan tunika mukosa, submukosa, muskularis, dan serosa dengan menggunakan calzeiss teaching microscope. Data yang diperoleh kemudian dianalisis. Hasil pengamatan dari morfometri struktur anatomi dan histologi dianalisis secara deskriptif kualitatif, sedangkan panjang, lebar, dan tebal secara deskriptif kuantitatif.

\section{HASIL DAN PEMBAHASAN}

\section{Morfologi Duodenum}

Hasil menunjukkan bahwa morfologi anatomi duodenum anjing kintamani betina berjalan secara kaudal dan melintang melalui tuber coxae, membentuk putaran berbentuk huruf $U$, hal ini sama halnya dengan yang disampaikan oleh Evans (1993). Bagian kranial duodenum berada di dorsal bagian kanan, dan berlawanan dengan ruang intercoste kesembilan, kemudian duodenum menjulur mengikuti dinding perut bagian kanan sampai pada lumbar keempat dan keenam. Pada bagian ini dinding duodenum dorsal berhubungan dengan pankreas, ventral berhubungan dengan jejunum, dan medial berhubungan dengan kolon dan sekum, selanjutnya duodenum menjulur kearah cranial berada digaris tengah tubuh diantara kolon dan akar mesenterium (Dyce, 2010).

Hasil penelitian menunjukkan bahwa struktur histologi duodenum anjing kintamani betina tersusun oleh empat lapisan, tunika mukosa, submukosa, muskularis dan serosa. Tunika mukosa merupakan bagian paling dalam pada lapisan duodenum. Banyak kelenjar yang mengeluarkan lendir ke dalam lumen untuk melumasi dinding usus melindungi dari gesekan cyme. Tunika mukosa terdiri dari tiga lapisan, lamina mukosa, propria, dan muskularis seperti yang dilaporkan oleh William et al. (2012) dan Althnaian et al. (2013). 


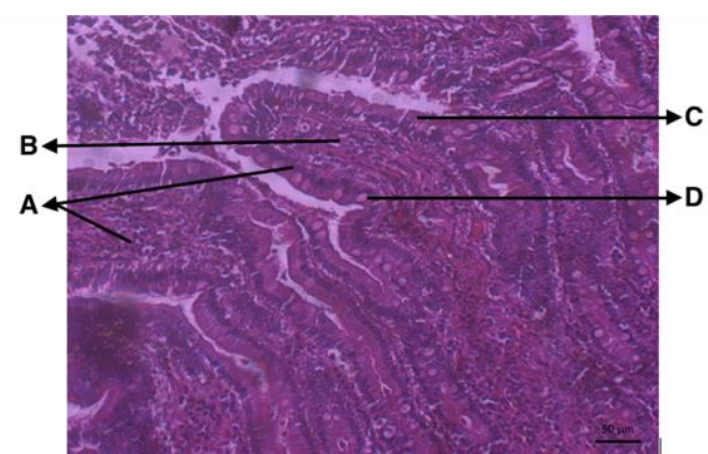

Picture 1. Tunica Mucousa (HE) (200X) A: Villi, B: Lamina Propria, C: Epitel, D: Goblet cell

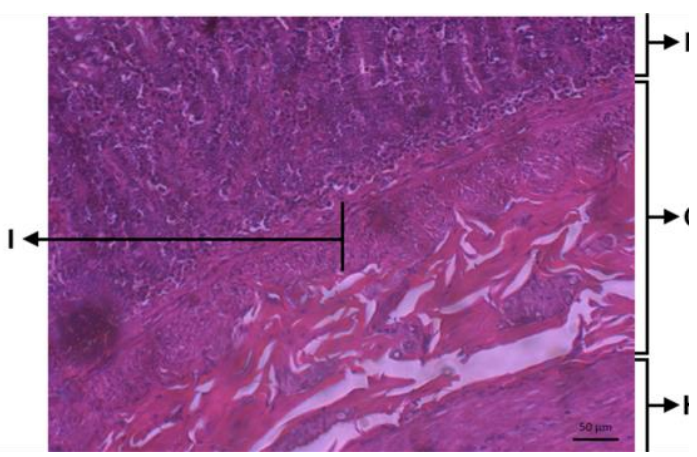

Picture 3. Histologi Duodenum (HE) (200X) F: Tunica Mucousa, G: Tunica Submucousa, H: Tunica Muscularis I: Lamina Muscularis

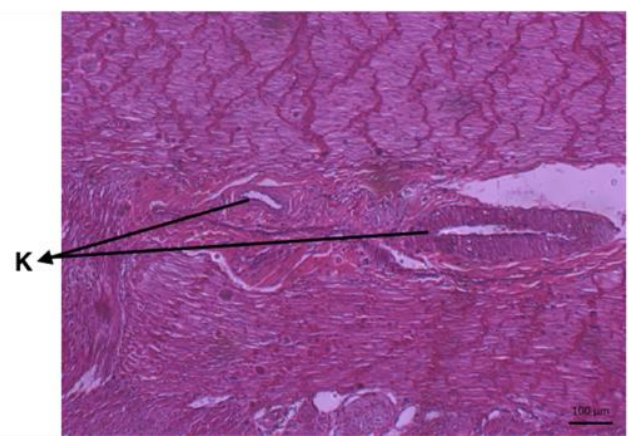

Picture 5. Tunica Muscoularis (HE) (200X), K: Blood vessel
DOI: 10.24843/bulvet.2020.v12.i01.p03

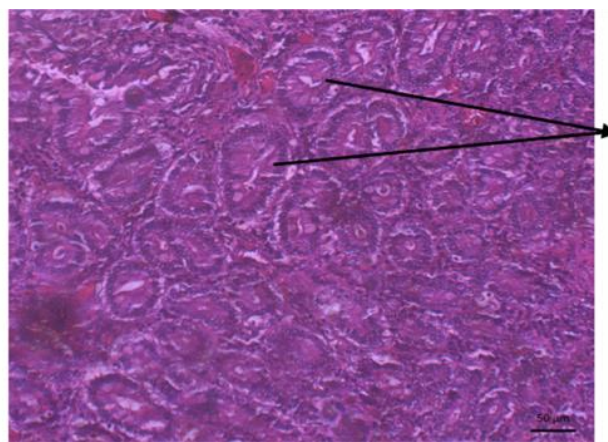

Picture 2. Tunica Mucousa (HE)

(200X) E: Crypt Lieberkuhn

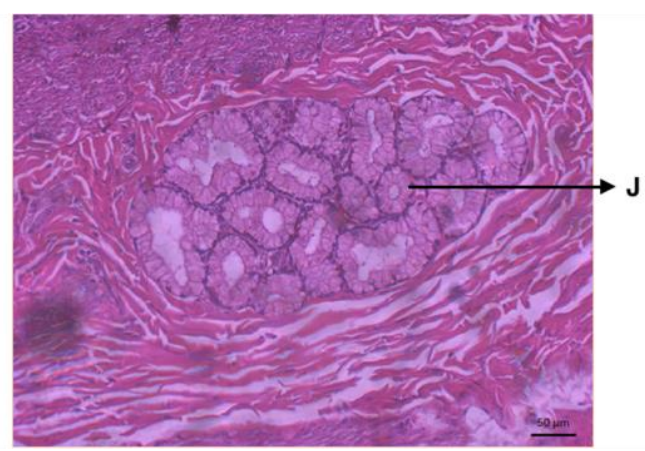

Picture 4. Tunica Submucousa (HE) (200X), J: Kelenjar Sekresi

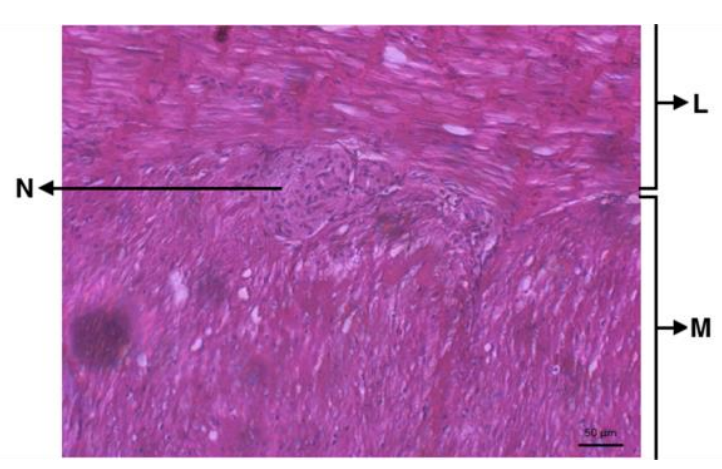

Picture 6. Tunica Muscoularis (HE) (200X) L: Muscularis sirculair, M: Muscularis Longitudinal, N: Nerve. 
Epitel yang ditemukan pada duodenum anjing kintamani yaitu epitel kolumner simplek. Lamina mukosa terdiri dari epitel kolumner simplek. Didalam tunika mukosa terdapat villi pada duodenum. Villi berfungsi untuk memperluas permukaan penyerapan. Sel-sel yang ditemukan di epitel adalah sel kolumner "sel absorptif". Sel goblet terpencar di antara sel kolumnar villi dan kriptus. Lamina propria menempati sebagian besar tunika mukosa. Lamina propria diperluas melalui inti villi, terdiri dari jaringan ikat longgar yang membentuk kerangka tunika mukosa, pembuluh darah, pembuluh getah bening dan otot polos (Althnaian et al., 2013). Lamina propria mengandung serabut elastis, leukosit, dan otot polos yang bersifat soliter berjalan dari muskularis mukosa sampai ke ujung villus (Suwiti, 2012).

Sel-sel yang ditemukan dalam lamina propria adalah sel goblet, crypt lieberkuhn, sama halnya yang dilaporkan oleh William et al. (2012). Sel goblet atau biasanya disebut sel mangkok letaknya tersebar diantara sel penyerap dan melekat pada juxta-luminal junctional complex, daerah kutub basalnya menyempit dan mengndung inti dan sitoplasma bersifat basofil (Suwiti, 2012). Lamina muskularis adalah lapisan otot polos yang memisahkan tunika mukosa dengan tunika submukosa (Althnaian et al., 2013). Pada lapisan tunika submukosa ditemukan kelenjar brunner dan unit sekresi. Pada lapisan tunika muskularis terdapat 2 lapisan muskularis longitudinal dan sirkular, kemudian terdapat pembuluh darah dan saraf, lapisan tunika muskularis yang berisi jaringan otot polos. Otot akan berkontraksi jika adanya chyme dan mendorongnya, hal ini diperkuat dari laporan William et al. (2012). Serosa adalah lapisan terluar dari duodenum yang berfungsi sebagai kulit luar usus. Membran serosa yang terbuat dari epitel skuamosa sederhana memberikan permukaan licin dan mulus untuk mencegah friksi antara duodenum dan organ di sekitarnya. Serosa juga mengeluarkan cairan serosa untuk lebih mengurangi gesekan dan menjaga duodenum. Pada lapisan tunika serosa terdiri dari jaringan ikat longgar yang berlanjut dengan mesenterium.

\section{Morfometri Duodenum}

Tabel 1. Rerata Panjang dan Lebar Duodenum Anjing Kintamani.

\begin{tabular}{lc}
\hline & Rata-rata \pm St Dev $(\mathrm{cm})$ \\
\hline Panjang & $16.2 \pm 1.3$ \\
Lebar & $3.1 \pm 0.1$ \\
\hline
\end{tabular}

Berdasarkan hasil pengukuran panjang duodenum anjing kintamani betina adalah $16,2 \pm 1,3 \mathrm{~cm}$ ini terbilang pendek dibandingkan dengan panjang duodenum anjing yang dilaporkan oleh Evans. (1993) yang memiliki panjang $25 \mathrm{~cm}$. Lebar duodenum anjing kintamani adalah 3,1 \pm $0,1 \mathrm{~cm}$.

Tabel 2. Rerata Ketebalan Lapisan Mukosa, Submukosa, Muskularis, dan Serosa

\begin{tabular}{ll}
\hline & Rata-rata \pm \\
& St Dev $(\mu \mathrm{m})$ \\
\hline Mukosa & $1364.584 \pm$ \\
& 255.504 \\
Sub mukosa & $360.136 \pm$ \\
& 188.283 \\
Muskularis & $689.178 \pm$ \\
Serosa & 267.228 \\
\hline
\end{tabular}

Berdasarkan hasil pengukuran lapisan duodenum anjing kintamani ketebalan tunika mukosa adalah 1.364,5 $\pm 255,5 \mu \mathrm{m}$ dimana ketebalan tunika mukosa pada anjing kintamani betina ini lebih tipis dibandingkan dengan tunika mukosa pada anjing yang dilaporkan oleh Roux (2015) yang memiliki ketebalan $3,54 \pm 0,74 \mathrm{~mm}$ $(3,540 \mu \mathrm{m})$. Ketebalan tunika mukosa anjing beagle adalah 3.613,0 $\pm 170,6 \mu \mathrm{m}$ (Conto et al., 2014), hal ini menunjukkan bahwa tunika mukosa anjing kintamni lebih tipis dibandingkan dengan anjing beagle.

Ketebalan tunika submukosa anjing kintamani adalah $360,1 \pm 188,2 \mu \mathrm{m}$ dimana ketebalan tunika submukosa pada anjing kintamani ini lebih tebal dibandingkan dengan tunika submukosa pada anjing yang 
dilaporkan oleh Roux (2015) yang memiliki ketebalan 0,26 $\pm 0,08 \mathrm{~mm}$ (260 $\mu \mathrm{m})$. Ketebalan tunika submukosa anjing beagle adalah 227,0 $\pm 16,8 \mu \mathrm{m}$ (Conto et al., 2014), hal ini menunjukkan bahwa ketebalan tunika submukosa anjing kintamani lebih tebal dibandingkan dengan anjing beagle.

Ketebalan tunika muskularis anjing kintamani adalah $689,1 \pm 267,2 \mu \mathrm{m}$ dimana ketebalan tunika muskularis pada anjing kintamani betina ini lebih tipis dibandingkan dengan dengan tunika muskularis pada anjing yang dilaporkan oleh Roux (2015) yang memiliki ketebalan $1,04 \pm 0,35 \mathrm{~mm}(1,004 \mu \mathrm{m})$. Ketebalan tunika muskularis anjing beagle adalah 1.168,3 $\pm 100,1 \mu \mathrm{m}$ (Conto et al., 2014), hal ini menunjukkan bahwa ketebalan tunika muskularis anjing kintamani lebih tipis dibandingkan dengan anjing beagle. Ketebalan tunika serosa adalah 25,8 $\pm 11,9$ $\mu \mathrm{m}$ dimana ketebalan tunika serosa pada anjing kintamni betina ini lebih tebal dibandingkan dengan tunika serosa pada anjing yang dilaporkan oleh Roux (2015) yang memiliki ketebalan $0,02 \pm 0,01 \mathrm{~mm}$ (20 $\mu \mathrm{m})$.

\section{SIMPULAN DAN SARAN}

\section{Simpulan}

Secara morfologi anatomi duodenum anjing kintamani berjalan secara caudal dan melintang melalui tuber coxae, membentuk putaran berbentuk huruf U. Morfologi histologi tersusun oleh empat lapisan yakni lapisan tunika mukosa, submukosa, muskularis dan serosa. Duodenum anjing kintamani secara morfometri anatomi yakni panjang duodenum $16,2 \pm 1,3 \mathrm{~cm}$ dan lebar duodenum $3,1 \pm 0,1 \quad \mathrm{~cm}$. Morfometri histologi yakni tunika mukosa $1.364,584 \pm 255,504 \mu \mathrm{m}$, tunika submukosa $360,136 \pm 188,283 \mu \mathrm{m}$, tunika muskularis $689,178 \pm 267,228 \mu \mathrm{m}$, dan tunika serosa $25,888 \pm 11,93 \mu \mathrm{m}$.

\section{Saran}

Adapun saran dari penulis untuk penelitian ini adalah perlu adanya penelitian lebih lanjut mengenai morfologi dan morfometri dari jejunum dan ilium. Sehingga nantinya diketahui perbedaan antara ketiga bagian usus halus pada anjing kintamani.

\section{DAFTAR PUSTAKA}

Althnaian TA, Alkhodair KM, Albokhadaim LF, Abdelhay MA, Homeida AM, El-Bahr SM. 2013. Histological and histochemical investigation on duodenum of dromedary camels (Camelus dromedarius). Sci. Int. 1(6): 217-221.

Wirawan IG, Widiastuti SK, Batan IW. Laporan kasus: Demodekosis pada anjing lokal Bali. Indonesia Medicus Veterinus. 8(1): 9-18.

Conto CD, Oervermanm A, Burgener IA, Doherr MG, Blum JW. 2010. Gastrointestinal tract mucosal histomorphometry and epithelial cell proliferation and apoptosis in neonatal and adult dogs. Am. Soc. Anim. Sci. 88: 2255-2264.

Dellman HD, Brown EM. 1987. Textbook of Veterinary Histology. Lea \& Febiger.

Dyce KM, Wensing CJG. 2009. Text Book of Veterinery Anatomy. 4th ed. Pp. 438447.

Evans HE. 1993. Anatomy of the Dog. 3rd ed. Library of Congress Cataloging-inPublication Data. Pp. 441-441.

Gunawan WNF, Sukada IM, Puja IK. 2012. Perilaku bermasalah pada anjing kintamani Bali. Buletin Veteriner Udayana. 4(2): 95-100.

Kiernan JA. 2010. General oversight stains for histology and histopatology, education guide: Special stains and H\&E 2nd. North America, Carpinteria, Californi, Dako. Pp. 29-36.

Luna LG. 1968. Manual Histologic Staining Methods of Pathology. 3rd Ed. The Blakiston Division Mc Graw-hill Book Company.

Puja IK. 2007. Anjing Kintamani Bali Maskot Fauna Kabupaten Bangli. Penerbit Universitas Udayana. Bali. 
Roux ABL. 2015. Correlation of Ultrasonographic Small Intestinal Wall Layering with Histology in Normal Dogs. Lousiana State University.

Suwiti NK, Suastika IP, Swacita IBN, Besung INK. 2015. Studi histologi dan histomorfometri daging sapi bali dan wagyu. J. Vet. 16(3): 432-438
Suwiti NK. 2012. Sistem Pencernaan. Buku Ajar. Fakultas Kedokteran Hewan Universitas Udayana.

William J, Bacha JR, Linda MB. 2012. Color Atlas of Veterinery Histology. 3ed. British Library. Pp. 163-166. 